\title{
Chronic Urticaria in the Real-Life Clinical Practice Setting in Portugal: Baseline Results from the Non-Interventional Multicentre AWARE Study
}

\author{
Urticária Crónica na Prática Clínica de Vida Real em \\ Portugal: Características Basais do Estudo Multicêntrico \\ Não-Intervencional AWARE
}

Célia COSTA ${ }^{1}$, Isabel ROSMANINHO ${ }^{2}$, Arminda GUILHERME ${ }^{2}$, José FERREIRA ${ }^{2}$, Joana ANTUNES ${ }^{3}$, Ana PINA $^{3}$, Sara PRATES ${ }^{4}$, João Gaspar MARQUES ${ }^{4}$, Filomena AZEVEDO ${ }^{5}$, Ana Paula CUNHA ${ }^{5}$, Celeste BRITO ${ }^{6}$, António MASSA ${ }^{7}$, João Teles de SOUSA ${ }^{8}$, Glória Cunha VELHO ${ }^{9}$, Inês RAPOSO ${ }^{9}$, Gabriela Marques PINTO ${ }^{10}$, Virgínia SOUSA ${ }^{10}$, Ana Rodrigues MARTINS ${ }^{11}$

Acta Med Port 2019 Feb;32(2):133-140 - https://doi.org/10.20344/amp.9496

\section{ABSTRACT}

Introduction: There is a paucity of information regarding chronic urticaria patients' care in a real-world setting. The objective of this study was to report and evaluate the baseline characteristics of Portuguese chronic urticaria patients refractory to $\mathrm{H} 1$-antihistamines included in the AWARE study.

Material and Methods: This is a non-interventional cohort study. Adult patients with a diagnosis of chronic urticaria with symptoms for at least two months, refractory to $\mathrm{H} 1$-antihistamines, consulting one of the 10 participating urticaria centers throughout Portugal have been included in the study. Baseline sociodemographic data, medical history, clinical parameters, medication, weekly urticaria activity score, and dermatology quality of life index have been collected.

Results: Seventy six patients were included, of which $76.3 \%$ were women. The majority of patients had a diagnosis of chronic spontaneous urticaria (88.2\%) and $39.5 \%$ had angioedema. Around $91.0 \%$ of patients were medicated with non-sedative $\mathrm{H} 1$ antihistamines and $35.4 \%$ with a third line therapy. Median dermatology quality of life index was 5.0 and median weekly urticaria activity score was 13.0.

Discussion: The baseline results suggest that patients with chronic urticaria refractory to $\mathrm{H} 1$-antihistamines are being under-treated in the real-world setting.

Conclusion: The AWARE study demonstrates the real impact of chronic urticaria on Portuguese patients refractory to $\mathrm{H} 1$-antihistamines treatment, and $30 \%$ report a very large or extremely large deleterious effect on their quality of life. The follow-up of these patients will allow evaluating strategies aimed at optimizing disease control.

Keywords: Chronic Disease; Cost of Illness; Health Resources; Portugal; Quality of Life; Urticaria

\section{RESUMO}

Introdução: A informação sobre os doentes com urticária crónica em ambiente de vida real é escassa e este estudo teve por objectivo reportar e avaliar as características basais dos doentes portugueses com urticária crónica refractários aos anti-histamínicos $\mathrm{H} 1$ incluídos no estudo AWARE.

Material e Métodos: Estudo de coorte não intervencional. Foram incluídos doentes adultos com diagnóstico de urticária crónica sintomáticos durante pelo menos dois meses, refratários aos anti-histamínicos $\mathrm{H} 1$, seguidos em 10 centros de urticária em Portugal. Foram recolhidos dados basais sociodemográficos, história clínica, parâmetros clínicos, medicação, índice semanal de atividade de urticária e índice de qualidade de vida dermatológico.

Resultados: Foram incluídos 76 doentes, dos quais $76,3 \%$ mulheres. A maioria dos doentes estava diagnosticado com urticária crónica espontânea (88,2\%) e 39,5\% apresentavam angioedema. Cerca de 91,0\% dos doentes estavam medicados com anti-histamínicos H1 não sedativos e 35,4\% com terapêuticas de terceira linha. A mediana do índice de qualidade de vida dermatológico foi 5,0 e a mediana do índice semanal de atividade de urticária foi 13,0.

Discussão: Os resultados basais sugerem que os doentes com urticária crónica refratários ao tratamento com anti-histamínicos H1 estão sub-tratados em ambiente de vida real.

Conclusão: $O$ estudo AWARE vem demonstrar o real impacto da urticária crónica nos doentes portugueses refratários ao tratamento com anti-histamínicos $\mathrm{H} 1$ onde mais de $30 \%$ reporta um impacto elevado ou extremamente elevado da doença na sua qualidade de vida. O seguimento destes doentes permitirá avaliar estratégias para otimização do controlo da doença.

Palavras-chave: Custo da Doença; Doença Crónica; Portugal; Qualidade de Vida; Recursos da Saúde; Urticária

1. Serviço de Imunoalergologia. Hospital de Santa Maria. Centro Hospitalar Lisboa Norte. Lisboa. Portugal.

2. Serviço de Imunoalergologia. Centro Hospitalar de Vila Nova de Gaia/Espinho. Vila Nova de Gaia. Portugal.

3. Serviço de Dermatologia. Hospital de Santa Maria. Centro Hospitalar Lisboa Norte. Lisboa. Portugal.

4. Serviço de Imunoalergologia. Hospital Dona Estefânia. Centro Hospitalar Lisboa Central. Lisboa. Portugal.

5. Serviço de Dermatologia. Centro Hospitalar de São João. Porto. Portugal.

6. Serviço de Dermatologia. Hospital de Braga. Braga. Portugal.

7. Serviço de Dermatologia. Centro Hospitalar de Vila Nova de Gaia. Vila Nova de Gaia. Portugal.

8. Serviço de Dermatologia. Hospital Egas Moniz. Centro Hospitalar Lisboa Ocidental. Lisboa. Portugal.

9. Serviço de Dermatologia. Centro Hospitalar do Porto. Porto. Portugal.

10. Serviço de Dermatologia. Hospital dos Capuchos. Centro Hospitalar Lisboa Central. Lisboa. Portugal.

11. Novartis Farma - Produtos Farmacêuticos, S.A. Porto Salvo. Portugal.

$\triangle$ Autor correspondente: Célia Costa. anaceliacosta@sapo.pt

Recebido: 27 de julho de 2017 - Aceite: 17 de setembro de 2018| Copyright @ Ordem dos Médicos 2019 


\section{INTRODUCTION}

Urticaria is a troublesome skin disease which causes red, swollen, itching and sometimes painful raised areas or 'wheals' on the skin. ${ }^{1}$ Chronic urticaria (CU) is diagnosed clinically by the typical itchy wheals that last less than 24 hours at each site, and recurrently appear for at least six weeks, in contrast to acute urticaria. ${ }^{2}$ The prevalence of CU is estimated to be between $0.1 \%$ and $1.0 \%{ }^{3}$ and patients may suffer from two or more types of CU. In Portugal, there is no epidemiological information about this patient population.

There are two types of $\mathrm{CU}$ : the chronic spontaneous urticaria (CSU) and the chronic inducible urticaria (CIndU). In contrast to CSU, in CIndU an external trigger can be found. ${ }^{2}$ $\mathrm{CU}$ has a significant impact on the patients' quality of life (QoL), resulting in high direct and indirect costs, namely with medication, physician appointments, visits to the Emergency Room (ER), hospitalizations and absenteeism. ${ }^{4}$

Existing guidelines show discrepancies on how $\mathrm{CU}$ should be tested and which tests should be performed. . $^{2,-9}$ However, once a diagnosis is established, it is consensual that the therapeutic goal is the complete control of $\mathrm{CU}$ symptoms, ${ }^{2,4,6,9,10}$ assessed by the weekly urticaria activity

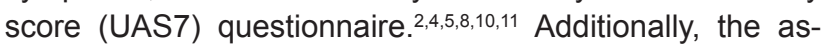
sessment of QoL, namely using the dermatology quality of life index (DLQI), is highly recommended..$^{1,8,9}$

As for the therapeutic approach to $\mathrm{CU}$, non-sedative $\mathrm{H} 1$ antihistamines $(\mathrm{H} 1-\mathrm{AH})$ are consensual as first-line therapy in $\mathrm{CU}$ patients ${ }^{2,4-10}$ and, in refractory patients, adjusting up to four times the approved dose is recommended as secondline therapy. 2,4-8,10,11

For patients refractory to second-line therapies, thirdline omalizumab ${ }^{2,4,6,9,10}$ or cyclosporine ${ }^{2,4-6,8}$ were recommended until $2014,{ }^{3-6,8,9,12}$ with omalizumab being on-label for $\mathrm{CSU}^{13}$ whilst cyclosporine was off-label ${ }^{14}$. However, and given more recent scientific data, omalizumab is currently recommended as a third-line therapy and cyclosporine as a fourth-line therapy. ${ }^{15}$

Several guidelines and expert opinions recommend a short course of oral corticosteroids only in exacerbations $2,4-10,12,13,16,17$ and, due to the risk of serious adverse events, do not recommend their long-term use. 2,4,8,9,12,16-18 Sedative $\mathrm{H} 1-\mathrm{AH}$ are no longer recommended due to their potential adverse events. ${ }^{2,8,10,19}$ The recommendations for Portugal on the diagnostic and therapeutic approach of CSU have been recently published. ${ }^{20}$

It has been recognized that the resources allocated to diagnose and treat $\mathrm{CU}$ patients should be adequate, and that the research into socioeconomic implications needs to be extended. ${ }^{3}$ Given the paucity of information regarding these patients' care in a real-world setting, an observational study was designed. AWARE is a non-interventional international multicenter study designed to evaluate the realworld disease burden of $\mathrm{CU}$ patients' refractory to $\mathrm{H} 1-\mathrm{AH}$ standard dose treatment, at specialized urticaria centers, as well as the therapies that are used, and the impact they have on QoL and work productivity of individual patients.
The objective of this work is to report the baseline characteristics of the Portuguese sample included in the AWARE study reflecting the current status of chronic urticaria management in Portugal. These results will allow for the identification of pitfalls in the real-world setting, and only this knowledge can lead to a better care of these patients.

\section{MATERIAL AND METHODS \\ Study design}

The AWARE study was designed to evaluate the realworld disease burden of adult patients with a diagnosis of $\mathrm{CU}$ for at least two months, refractory to $\mathrm{H} 1-\mathrm{AH}$ standard dose, at specialized urticaria centers, as well as the therapies that are used, and the impact they have on QoL and work productivity of individual patients. The study was approved by the Ethics Committee of each participating center and conducted according to the tenets of the Declaration of Helsinki as revised in 1983.

\section{Setting and participants}

The AWARE study is a non-interventional international multicenter study that was conducted worldwide in 36 countries. This paper pertains only to patients recruited from the 10 participating centers throughout Portugal, from October $31^{\text {st }} 2014$ to July $31^{\text {st }} 2015$. In this cohort study, all study variables were collected at baseline and then will be collected approximately every three months, during a follow-up period of two years, for a total of nine visits (Table 1). Diagnosis of urticaria was confirmed at enrollment according to the European guidelines. ${ }^{2}$

Inclusion criteria were: written informed consent of the patient to participate in the study; age 18 years or more; medically confirmed diagnosis of chronic urticaria present for more than two months; refractory to treatment with standard dose of $\mathrm{H} 1-\mathrm{AH}$. Exclusion criteria were: anticipated difficulties of follow-up during at least two years; participating in any other clinical urticaria study.

\section{Methods of assessment}

All variables were collected on an eCRF specifically designed for the study. Patient reported outcomes, UAS7 $7^{2,4,5,8,10,11}$ and DLQI, ${ }^{1,8,9}$ were filled by patients during the consultation and scores were introduced on the eCRF. The UAS7 is a questionnaire that measures disease activity within seven days. According to UAS7, an UAS7 = 0 means urticaria-free, UAS7 between 1 - 6 well controlled urticaria, 7 - 15 mild urticaria, 16 - 27 moderate urticaria and between 28 - 42 severe urticaria. ${ }^{21,22} \mathrm{~A}$ patient is considered to have symptoms reasonably controlled with an UAS7 $\leq 6 .{ }^{10} \mathrm{DLQ}$ is a dermatology QoL questionnaire. According to DLQI, a score between 0 - 1 indicates that the urticaria has no effect on patient's life, 2 - 5 that it has a small effect on patient's life, 6 - 10 that it has a moderate effect, 11 - 20 a very large effect, and between 21 - 30 an extremely large effect. ${ }^{23,24}$ Body mass index (BMI) was calculated as $\mathrm{kg} / \mathrm{m}^{2}$. 
Table 1 - Variables recorded at enrollment (visit 1), and planned to be recorded during follow-up

\begin{tabular}{|c|c|}
\hline Variable & Visit \\
\hline Sociodemographic data (age, gender, height, weight) & 1 \\
\hline Medical history & 1 \\
\hline Diagnostic procedure(s) for further classifying $\mathrm{CU}$ & 1 \\
\hline Time of first onset of disease until enrollment & 1 \\
\hline $\begin{array}{l}\text { Comorbidities (including asthma, allergic rhinitis, atopic dermatitis, eczema, nut allergy, depression, anxiety disorders, } \\
\text { psychosomatic diseases, Hashimoto thyroiditis, type } 1 \text { diabetes, vitiligo, lupus erythematosus, obesity, hypertension, } \\
\text { hypertriglyceridemia) }\end{array}$ & $1,5,9$ \\
\hline Previous, current and newly prescribed medication & All \\
\hline Presence of angioedema at baseline/since last visit & All \\
\hline Intensity and duration of angioedema & All \\
\hline \multicolumn{2}{|l|}{ Presence of wheals at baseline/since last visit } \\
\hline $\begin{array}{l}\text { Type and frequency of utilization of medical resources (emergency room, primary care, other specialized care, } \\
\text { hospitalization) }\end{array}$ & All \\
\hline Disease burden (including impact on sleep and work/study productivity) & All \\
\hline Response to each substance class & All \\
\hline Spontaneous remission & All \\
\hline UAS7 & All \\
\hline DLQI & All \\
\hline
\end{tabular}

\section{Quantitative variables and groups}

This paper reports the baseline characteristics of patients included in the AWARE study in Portugal. In addition to descriptive statistics, inference statistics was performed for each variable in Table 1 as the dependent variable, and time from diagnosis to enrollment in the study, baseline UAS7 and DLQI scores as the independent variables. Further analysis was performed according to having the symptoms controlled or not, and according to DLQI $\leq 5$, DLQI between 6 - 10, and DLQI $\geq 11 .^{23,24}$

\section{Statistical methods}

After testing for the normality of all variables using the Kolmogorov-Smirnov test, non-parametric statistics methods were used. Continuous variables are presented as median (minimum-maximum) and categorical variables as percentages. Between group analysis was performed using the Mann-Whitney $U$, the Kruskal-Wallis test or the $\chi^{2}$ test, as appropriate. Correlations were assessed with the Spearman $\rho$ test. Exploratory univariate analyses were performed, followed by multivariate regression analyses to determine predictors of medical resources utilization. The variables selected for the multivariate analyses were those statistically significant from the univariate analyses and clinically relevant variables. On logistic regression using the enter method, the dependent variable was medical resources utilization (4 regressions were performed, one for each dependent variable, dichotomized as $0=$ no $1=$ yes) and the used predictor variables were DLQI, gender, presence/ absence of wheals, presence/absence of angioedema, and urticaria duration (in years). The Bonferroni correction was applied to univariate analyses when necessary. Tests were considered significant at $\alpha=0.05$ significance level (two- sided). The software used was SPSSv20.

\section{RESULTS \\ Participants}

Of the 5237 patients included worldwide in the AWARE study, the 76 patients included in the study in Portugal were analyzed. All tables state the number of patients with data available for each analyzed variable. Missing data were considered to be missing completely at random (MCAR).

\section{Demographic and clinical baseline characteristics}

The median age of the study cohort was 46.5 years and the majority of participants were women (76.3\%). Almost $87.0 \%$ of patients had wheals at baseline and $39.5 \%$ presented with angioedema. The majority of angioedema intensity was mild to moderate, with a median duration of 24 hours. Twenty six percent of patients had a diagnosis of urticaria for less than 1 year, $32.8 \%$ for 2 to 5 years, $21.9 \%$ for 6 to 10 years, and the remaining $18.7 \%$ for more than 10 years. Seventy five percent of patients reported having comorbidities, with the most frequent being cardiometabolic $(52.6 \%)$ and depression $(40.4 \%)$, followed by anxiety and allergic rhinitis, each with $35.1 \%$ (Table 2).

\section{Medical resources utilization and absenteeism}

Since diagnosis, $51.0 \%$ of patients had gone to the ER at least once due to urticaria before the observational period of the study, $5.3 \%$ had been hospitalized, and $50.0 \%$ had attended at least one primary care consultation (Table 3 ). Additional analysis showed that, of the patients attending an ER or a primary care consultation, $57.9 \%$ and $58.4 \%$, respectively, used these resources 3 or more times. Almost $50.0 \%$ of patients attending other specialized care units 
Table 2 - Demographic and clinical baseline characteristics of the Portuguese patients included in the AWARE study

\begin{tabular}{|c|c|}
\hline Variable & $\begin{array}{l}\text { Population cohort } \\
\qquad(\mathrm{n}=76)^{*}\end{array}$ \\
\hline Age, median (min. - max.) & $46.5(19.0-86.0)$ \\
\hline \multicolumn{2}{|l|}{ Gender } \\
\hline Women, n (\%) & $58(76.3)$ \\
\hline Presence of wheals, $n(\%)$ & $66(86.8)$ \\
\hline Presence of angioedema, $\mathrm{n}(\%)$ & $30(39.5)$ \\
\hline \multicolumn{2}{|l|}{ Intensity of angioedema, n (\%) } \\
\hline Mild & $13(43.3)$ \\
\hline Moderate & $15(50.0)$ \\
\hline Severe & $2(6.7)$ \\
\hline Duration of angioedema (hours), median (min. - max.) & $24.0(1.0-72.0)$ \\
\hline Years since urticaria diagnosis $(n=64)^{\dagger}$, median (min. - max.) & $4.0(0.0-45.0)$ \\
\hline$<1, \mathrm{n}(\%)$ & $17(26.6)$ \\
\hline $2-5, n(\%)$ & $21(32.8)$ \\
\hline $6-10, \mathrm{n}(\%)$ & $14(21.9)$ \\
\hline$>10, \mathrm{n}(\%)$ & $12(18.8)$ \\
\hline BMI $\left(\mathrm{kg} / \mathrm{m}^{2}\right)$, median (min. - max.), $n=73$ & $25.9(18.4-41.5)$ \\
\hline Co-morbidities, n (\%) & $57(75.0)$ \\
\hline \multicolumn{2}{|l|}{ Most frequent co-morbidities $(>20 \%)^{\ddagger}$} \\
\hline Cardiometabolic§, n (\%) & $30(52.6)$ \\
\hline Depression, n (\%) & $23(40.4)$ \\
\hline Anxiety, n (\%) & $20(35.1)$ \\
\hline Allergic rhinitis, n (\%) & $20(35.1)$ \\
\hline
\end{tabular}

${ }^{*} \mathrm{n}: 76$ unless otherwise specified; †: years since urticaria diagnosis at the date of the first baseline visit; $\ddagger$ : most frequent co-morbidities do not sum $100 \%$ due to several patients having multiple co-morbidities; §: cardiometabolic: include hypertension, hypercholesterolemia, hypertriglyceridemia, obesity, type 2 diabetes; min. - max.: minimum - maximum

used this resource 10 or more times, and $75.0 \%$ of patients who were hospitalized were admitted for 2 or more times. Patients with urticaria diagnosed for longer used primary care resources less frequently (Mann-Whitney $U=2.009$, $\mathrm{n}=64, p=0.045$ ), and patients that used other specialized care showed a better controlled urticaria than patients that did not use this medical resource $(n=41$, OR $=0.46$, $95 \% \mathrm{Cl}, 0.25-0.84, p=0.037)$. On multivariate logistic regression analysis, the dependent variable being medical resources utilization and the predictor variables being DLQI, gender, presence/absence of wheals, presence/absence of angioedema, and urticaria duration (in years), being female was a predictor of going to the ER, with women attending ER consultations 4 times more frequently than men $(n=76$, $\operatorname{Exp}(B)=4.038, p=0.021$ ).

Twenty six percent of patients had been on sick leave due to urticaria, with the major reason being wheals and pruritus, followed by wheals, pruritus and angioedema, and angioedema alone (Table 3).

\section{Diagnosis and most frequent diagnostic procedures for CU classification}

The majority of patients had a confirmed diagnosis of CSU $(88.2 \%)$, with the remaining $11.8 \%$ showing a variety of CIndU (Table 4). Twenty five percent of patients had a diagnosis of two or more urticarias. The most frequent laboratory tests performed for further classifying CSU were complete blood count (CBC), erythrocyte sedimentation rate (ESR) and C-reactive protein (CRP), all performed in more than $76.0 \%$ of patients, and the least frequent test was a skin biopsy, requested for $10.2 \%$ of patients (Table 4 ). The request for a biopsy was not associated with the reported wheal time being longer than 24 hours $\left(\chi^{2}(g l)=1.712\right.$, $\mathrm{n}=66, p=0.290)$. CBC, ESR and CRP were normal in more than $80.0 \%$ of patients. The most common additional tests performed in the $67 \mathrm{CSU}$ patients were skin prick

Table 3 - Utilization of medical resources and reasons for absenteeism of the Portuguese patients included in the AWARE study

\begin{tabular}{lc}
\hline Utilization of medical resources & $\begin{array}{c}\mathbf{n}(\%) \\
(\mathbf{n}=\mathbf{7 6})\end{array}$ \\
\hline Emergency Room & $39(51.3)$ \\
Primary care & $38(50.0)$ \\
Other specialized care & $30(39.5)$ \\
Hospitalization & $4(5.3)$ \\
\hline Reasons for absenteeism & $\mathbf{n}(\%)$ \\
\hline Wheals, pruritus and angioedema & $(\mathbf{n = 7 3 )}$ \\
Wheals and pruritus & 44 \\
Angioedema & 48 \\
\hline
\end{tabular}


Table 4 - Diagnosis of type of chronic urticarial and most frequent laboratory tests for CSU evaluation of the Portuguese patients included in the AWARE study

\begin{tabular}{lc}
\hline Type of chronic urticaria & $\begin{array}{c}\mathbf{n}(\%) \\
(\mathbf{n}=\mathbf{7 6})\end{array}$ \\
\hline Chronic spontaneous urticaria & $67(88.2)$ \\
Cold urticaria & $3(3.9)$ \\
Cholinergic urticaria & $2(2.6)$ \\
Delayed pressure urticaria & $2(2.6)$ \\
Solar urticaria & $1(1.3)$ \\
Aquagenic urticaria & $1(1.3)$ \\
\hline Most frequent laboratory tests for CsU evaluation & $\mathbf{n}(\%)$ \\
\hline Complete blood count & $61(91.0)$ \\
Erythrocyte sedimentation rate & $53(79.1)$ \\
C-reactive protein & $51(76.1)$ \\
Prick tests & $15(22.4)$ \\
Autologous serum skin test & $9(13.4)$ \\
Epicutaneous tests & $8(11.9)$ \\
Biopsy & $7(10.4)$ \\
\hline
\end{tabular}

CSU: chronic spontaneous urticaria

tests (SPT) $(n=15,22.4 \%)$, the autologous serum skin test (ASST) $(n=9,13.4 \%)$ and the epicutaneous tests $(n=8$, $11.9 \%)$. From these, results were positive in 7 (46.7\%) SPT, 5 (55.6\%) ASST, and 6 (75.0\%) epicutaneous tests.

\section{Medication at baseline}

The AWARE study only recruited documented CU patients that are refractory to the standard dose of $\mathrm{H} 1-\mathrm{AH}$ treatment; $90.8 \%$ of patients were medicated with nonsedative $\mathrm{H} 1-\mathrm{AH}, 12.3 \%$ with sedative $\mathrm{H} 1-\mathrm{AH}, 27.7 \%$ with montelukast, and $35.4 \%$ with a third line therapy at baseline (Table 5). Almost $11.0 \%$ of patients were taking oral corticosteroids.

\section{UAS7 and DLQI}

Despite the relatively high treatment rate, $43.9 \%$ of patients still presented moderate to severe urticaria, and only $29.3 \%$ of patients had well-controlled urticaria at enrollment (Table 6). Moreover, patients with angioedema during the previous six months had less well-controlled itch and hive than patients that had no additional angioedema during the previous six months $(n=41$, OR $=0.69,95 \% \mathrm{Cl}, 0.54-$ $0.88, p=0.039$ ).

Regarding QoL, 30.9\% of patients reported that urticaria had a very large or extremely large deleterious effect on their life and $21.1 \%$ reported that CU had no effect on their QoL under the current treatment (Table 6). Patients that had wheals in the previous six months showed higher DLQI scores (Mann-Whitney $U=1.993, n=76, p=0.046$ ) compared to patients that did not have wheals in the previous six months, and women reported higher DLQI scores than men (Mann-Whitney $U=2.035, \mathrm{n}=71, p=0.042$ ). There was a strong correlation between UAS7 and DLQI scores (Spearman $\rho=0.737, \mathrm{n}=38, p=0.001$ ).
Table 5 - Medication at baseline of the Portuguese patients included in the AWARE study

\begin{tabular}{lc}
\hline Medication & $\begin{array}{c}\mathbf{n}(\%) \\
(\mathbf{n}=\mathbf{6 5})\end{array}$ \\
\hline Non-sedative H1-antihistamines & $59(90.8)$ \\
Sedative H1-antihistamines & $8(12.3)$ \\
Montelukast & $18(27.7)$ \\
Omalizumab & $20(30.8)$ \\
Cyclosporine & $3(4.6)$ \\
Oral corticosteroids & $7(10.8)$ \\
Other & $7(10.8)$ \\
\hline
\end{tabular}

Out of the 76 patients, 65 answered answered the questions regarding medication at baseline. Medication at baseline does not sum 100\% due to several patients being polymedicated.

Other: adrenaline, heliotherapy, intravenous immunoglobulin, ranitidine.

Table 6 - Baseline UAS7 and DLQI cut-off scores of the Portuguese patients included in the AWARE study

\begin{tabular}{lc}
\hline UAS7 cut-off scores & $\begin{array}{c}\mathbf{n}(\%) \\
(\mathbf{n}=\mathbf{4 1 )}\end{array}$ \\
\hline $0-6$ & $12(29.3)$ \\
$7-15$ & $11(26.8)$ \\
$16-27$ & $12(29.3)$ \\
$28-42$ & $6(14.6)$ \\
\hline DLQI cut-off scores & $\mathbf{n}(\%)$ \\
\hline $0-1$ & $(\mathbf{n}=71)$ \\
$2-5$ & $15(21.1)$ \\
$6-10$ & $26(36.6)$ \\
$11-20$ & $8(11.3)$ \\
$21-30$ & $17(23.9)$ \\
\hline
\end{tabular}

UAS7: weekly urticaria activity score; DLQI: dermatology quality of life index

\section{DISCUSSION}

This observational study reflects the resources allocated to diagnose and treat chronic urticaria patients and describes the real-life setting and clinical management in the 10 participating urticaria centers throughout Portugal. Of the 5237 patients included worldwide in the AWARE study, the 76 patients included in the study in Portugal were analyzed.

The demographic characteristics of our cohort, namely median age and a predominance of the female gender, are in line with other studies, ${ }^{25-46}$ including the German and Scandinavian AWARE patients. ${ }^{47,48}$ This consistently reported female predominance is not explained, neither mechanistically nor clinically. ${ }^{35}$ Of notice, one large Japanese study ${ }^{49}$ showed only a slightly higher incidence of urticaria in women than in men $(5.8 \%$ vs $4.1 \%)$, and two Korean studies showed a slight predominance of women compared to men $^{50}$ or even a slight predominance of men compared to women. ${ }^{51}$ It may be speculated that, given $\mathrm{CU}$ is a multifactorial disease, the different genetic backgrounds and environmental factors currently recognized in western and eastern populations, have an impact in the urticaria gender incidence. 
As for the clinical characteristics, almost $87.0 \%$ of patients had wheals at baseline $e^{2,52,53}$ and $39.5 \%$ of patients presented additionally angioedema, which is also similar to other reports, ${ }^{25,26,29,43,45,54}$ including the German and Scandinavian AWARE baseline studies. ${ }^{47,48}$ Our results show that both wheals and angioedema independently negatively affect QoL and UAS7 scores, although angioedema is not part of the UAS7 questionnaire. It is clear that chronic wheals and angioedema have a serious burden on the QoL of CU patients.

Regarding co-morbidities, our results are in line with others, who have reported depression, anxiety and allergic rhinitis in $\mathrm{CU}$ patients, although with different frequencies. ${ }^{27,31,34,35,46,55}$

However, and although both the German and Scandinavian AWARE baseline studies also report these comorbidities, their frequencies are much lower than the ones found in our study. ${ }^{47,48}$. Both studies state that anxiety and depression were lower than expected, and suggest that this may be due to differences in the diagnostic criteria used, ${ }^{47,48}$ but this cannot be the case because the AWARE study used the same diagnostic criteria in all participating countries. Therefore, we can only speculate that perhaps comorbidities are somewhat neglected in Portuguese CU patients, since the main focus is to control CU. In fact, some authors stress the importance of a comprehensive, multidisciplinary approach to treat these patients, in order to offer them an appropriate psychotherapeutic intervention, when deemed necessary. ${ }^{34}$

One important aspect of $\mathrm{CU}$ is the use of medical resources by patients, which not only has personal and social implications, but also impacts on direct and indirect costs. A patient suffering from a poorly controlled CU will use more medical resources and probably have higher absenteeism from school or work. Before enrollment in the AWARE study, $51.0 \%$ of patients had gone to the ER at least once, of which $57.9 \%$ had used this resource three or more times. Being female was a predictor of going to the ER, which is consistent with women reporting higher DLQI scores than men. Supporting our results, women have been shown to have a greater burden of illness than men ${ }^{15}$ and to visit the ER more, thereby contributing to higher total costs. ${ }^{27,28}$ Also, $5.3 \%$ of patients were hospitalized and, of those, $75.0 \%$ were admitted two or more times. Of notice, almost $50.0 \%$ of patients attending other specialized care units had used this resource 10 or more times. The observation that patients with urticaria diagnosed for longer used primary care resources less, and patients that used other specialized care units showed a more well-controlled urticaria, suggests that patients tend to switch from primary care to specialized care as the urticaria persists, with positive results on the control of their urticaria. Different results regarding medical care resources utilization have been reported, and are usually high, ${ }^{26-28,30,46,55,56}$ leading to the conclusion that $\mathrm{CU}$ carries a substantial cost. ${ }^{27,55}$ It has been suggested that the types of medical resources differ among countries depending on local healthcare specificities, ${ }^{56}$ and this may explain the different medical care resources utilization re- ported by the German and Scandinavian AWARE baseline studies ${ }^{47,48}$ compared to ours. As for absenteeism, $26.0 \%$ of our patients had reported sick leave due to urticaria, with no gender differences, which is in line with the German and Scandinavian AWARE baseline studies. ${ }^{47,48}$

CBC, ESR and CRP were requested for the majority of patients, which is in agreement with the Portuguese recommendations. ${ }^{20}$ The additional tests requested, with the aim of further elucidating an underlying cause for the diagnosed urticaria, are also incorporated in the same guideline ${ }^{20}$ and are recommended based on physician's evaluation and patients' history. In our case, additional tests performed in the 67 CSU patients, namely SPT, ASST and the epicutaneous test, were positive in 7 (46.7\%), 5 (55.6\%) and 6 (75.0\%) patients, respectively, thus helping in a more accurate diagnosis of the type of urticaria.

Non-sedative $\mathrm{H} 1-\mathrm{AH}$ are consensual as first-line therapy in patients with urticaria ${ }^{2,4-10}$ and, in refractory patients, increasing up to 4 times the approved dose is recommended as second-line therapy. 2,4-8,10,11 In line with these recommendations, almost $91 \%$ of our patients were taking non-sedative $\mathrm{H} 1-\mathrm{AH}$ at enrollment. Other real-life settings have reported non-sedative $\mathrm{H} 1-\mathrm{AH}$ being used in $72.0 \%$ to $75.0 \%{ }^{26,28,42}$ of patients, either as first- or second-line. In the German AWARE study only $46.3 \%$ of patients were taking non-sedative $\mathrm{H} 1-\mathrm{AH}$, and the authors recognize that patients were undertreated. ${ }^{47}$ The same was true in the Scandinavian AWARE study that reported $40.5 \%$ of patients medicated with non-sedative $\mathrm{H} 1-\mathrm{AH}$ at baseline, whose treatment was increased on the first consultation to $87.3 \%$, also indicating that patients were undertreated. ${ }^{48}$

Given some of our patients were eligible for third-line therapies due to being refractory to first- and second-line therapies, and given $43.9 \%$ had moderate-to-severe urticaria, with $35.4 \%$ being medicated with a third-line therapy, $10.8 \%$ were taking oral corticosteroids at enrollment, in an attempt to control their symptoms, a percentage similar ${ }^{26}$ or lower ${ }^{28,33,37}$ than other real-life settings, including the German and Scandinavian AWARE studies ${ }^{47,48}$ (15.9\% and $19.0 \%$, respectively). In the Scandinavian AWARE study corticosteroids were reduced to $12.7 \%$ on the first consultation. ${ }^{48}$

Sedative $\mathrm{H} 1-\mathrm{AH}$ are no longer recommended due to their adverse events. ${ }^{2,8,10,19}$ Although in our study $12.3 \%$ of patients were taking sedative $\mathrm{H} 1-\mathrm{AH}$, a percentage higher than the German (9.1\%) and Scandinavian (3.2\%) AWARE studies, ${ }^{47,48}$ we agree they should not be used. Perhaps there is a need to convey this information more effectively, both to Portuguese primary care physicians and to all specialties that deal with urticaria, in order to stop prescribing sedative $\mathrm{H} 1-\mathrm{AH}$. However, the Scandinavian AWARE study only reduced sedative $\mathrm{H} 1-\mathrm{AH}$ to $2.5 \%$ on the first consultation. ${ }^{48}$

For patients refractory to second-line therapies, thirdline omalizumab2,4,6,9,10 or cyclosporine ${ }^{2,4-6,8}$ were recommended until $2014,,^{3-6,8,9,12}$ with omalizumab being on-label for $\mathrm{CSU}^{13}$ whilst cyclosporine was off-label. ${ }^{14}$ However, and 
given more recent scientific data, omalizumab is currently recommended as a third-line therapy and cyclosporine a fourth-line therapy. ${ }^{15}$ Cyclosporine should be used with caution due to its adverse events, or used only in specific groups of patients. . $^{2,5,6,8,10}$ In our population sample, $30.8 \%$ of patients were being treated with omalizumab as thirdline therapy and $4.6 \%$ with forth-line cyclosporine. These percentages are higher than the ones reported both in the German and Scandinavian AWARE studies (omalizumab: $2.1 \%$ and $8.2 \%$, respectively; cyclosporine: $1.4 \%$ and $2.5 \%$, respectively). ${ }^{47,48}$ However, the Scandinavian AWARE study increased omalizumab to $42.4 \%$ and decreased cyclosporine to $0.6 \%$ on the first consultation. ${ }^{48}$

Finally, $30.9 \%$ of our patients reported that urticaria symptoms had a very large or extremely large effect on their life, which is in line with the German AWARE study, ${ }^{47}$ and $43.9 \%$ presented with moderate to severe urticaria symptoms according to UAS7. The mean UAS7 score reported by the Scandinavian AWARE $(15.6)^{48}$ is similar to our median (13.0).

Analyses of our results of UAS7 and DLQI, together with the medication at baseline, suggest that these patients are being under-treated in the real-world setting, which has been reported in other study settings as well, ${ }^{30-33,35,36,57}$ including the German and Scandinavian AWARE baseline studies. ${ }^{47,48}$ These results suggest that physicians should be aware of the need to adequately treat these patients, in order to manage this disabling condition more effectively. ${ }^{30,57}$ The observed strong correlation between UAS7 and DLQI is in line with observations made by others. ${ }^{21,22,25}$

\section{Limitations}

The AWARE study recruited CU patients referred to specialized urticaria centers from public primary care services, due to being refractory to at least the approved H1-antihistamine dose. If patients were not previously diagnosed with $\mathrm{CU}$ or were followed only in the private setting they have not been included. The non-interventional, observational study design, depending on the information provided by the physician, is another limitation of this study.

\section{REFERENCES}

1. Jauregui I, Ortiz de Frutos FJ, Ferrer M, Giménez-Arnau A, Sastre $\mathrm{J}$, Bartra J, et al. Assessment of severity and quality of life in chronic urticaria. J Investig Allergol Clin Immunol. 2014;24:80-6.

2. Zuberbier T, Aberer W, Asero R, Bindslev-Jensen C, Brzoza Z, Canonica $\mathrm{GW}$, et al. The EAACI/GA(2) LEN/EDF/WAO Guideline for the definition, classification, diagnosis, and management of urticaria: the 2013 revision and update. Allergy. 2014;69:868-87.

3. Maurer M, Weller K, Bindslev-Jensen C, Giménez-Arnau A, Bousquet PJ, Bousquet J, et al. Unmet clinical needs in chronic spontaneous urticaria. A GA(2)LEN task force report. Allergy. 2011;66:317-30.

4. Wedi B, Wieczorek D, Raap U, Kapp A. Urticaria. J Dtsch Dermatol Ges. 2014;12:997-100.

5. Termeer C, Staubach P, Kurzen H, Stromer K, Ostendorf R, Maurer M. Chronic spontaneous urticaria - a management pathway for patients with chronic spontaneous urticaria. J Dtsch Dermatol Ges. 2015;13:41928.

6. Powell RJ, Leech SC, Till S, Huber PA, Nasser SM, Clark AT. BSACI guideline for the management of chronic urticaria and angioedema. Clin Exp Allergy. 2015;45:547-65.

\section{CONCLUSION}

The AWARE study provides real-world data on disease burden of $\mathrm{CU}$ patients refractory to $\mathrm{H} 1-\mathrm{AH}$ treatment, therapies used, and the impact they have on the quality of life and work productivity of individual patients. The baseline results reported in this paper suggest that these patients are being under-treated in the real-world setting in Portugal, which has been reported in other study settings as well. These results suggest that Portuguese physicians should be aware of the need to adequately treat these patients, in order to manage this disabling condition more effectively.

The prospective follow-up of these patients will allow for the identification of pitfalls in the real-world setting, improve diagnosis and optimize treatment, minimizing the direct and indirect consequences of $\mathrm{CU}$ in Portuguese patients.

\section{ACKNOWLEDGEMENTS}

The authors thank Novartis Farma for providing medical editorial assistance with this manuscript.

\section{PROTECTION OF HUMANS AND ANIMALS}

The authors declare that the procedures were followed according to the regulations established by the Clinical Research and Ethics Committee and to the Helsinki Declaration of the World Medical Association.

\section{DATA CONFIDENTIALITY}

The authors declare having followed the protocols in use at their working center regarding patients' data publication. Patient consent obtained.

\section{CONFLICTS OF INTEREST}

The authors declare collaborating and receiving fees from Novartis Farma and other pharmaceutical companies either through participation in advisory board or consultancy, congress symposia, clinical trial conduct, investigatorinitiated trials or grants. Author A Rodrigues Martins is an employee of Novartis Farma.

\section{FUNDING SOURCES}

This study was funded by Novartis Farma.

7. Maurer M, Magerl M, Metz M, Zuberbier T. Revisions to the international guidelines on the diagnosis and therapy of chronic urticaria. J Dtsch Dermatol Ges. 2013;11:971-7.

8. Ferrer M, Bartra J, Gimenez-Arnau A, Jauregui I, Labrador-Horrillo M, Ortiz de Frutos J, et al. Management of urticaria: not too complicated, not too simple. Clin Exp Allergy. 2015;45:731-43.

9. Bernstein JA, Lang DM, Khan DA, Craig T, Dreyfus D, Hsieh F, et al. The diagnosis and management of acute and chronic urticaria: 2014 update. J Allergy Clin Immunol. 2014;133:1270-7.

10. Sussman G, Hebert J, Gulliver W, Lynde C, Waserman S, Kanani A, et al. Insights and advances in chronic urticaria: a Canadian perspective. Allergy Asthma Clin Immunol. 2015;11:7.

11. Mitchell S, Balp MM, Samuel M, McBride D, Maurer M. Systematic review of treatments for chronic spontaneous urticaria with inadequate response to licensed first-line treatments. Int J Dermatol. 2015;54:1088104.

12. Schaefer P. Urticaria: evaluation and treatment. Am Fam Physician. 2011;83:1078-84

13. Maurer M, Vena GA, Cassano N, Zuberbier T. Current and future 
therapies for treating chronic spontaneous urticaria. Expert Opin Pharmacother. 2016;17:1131-9.

14. Summary of Product Characteristics Ciclosporine. Approved by Infarmed. 2012. [accessed 2017 Jun 20]. Available from: http://app7. infarmed.pt/infomed/download_ficheiro.php?med_id=7743\&tipo_ doc $=\mathrm{rcm}$.

15. Zuberbier T, Aberer W, Asero R, Abdul Latiff AH, Baker D, BallmerWeber B, et al. The EAACI/GA(2)LEN/EDF/WAO Guideline for the Definition, Classification, Diagnosis and Management of Urticaria. The 2017 Revision and Update. Allergy. 2018;73:1393-414.

16. Zuberbier T. Pharmacological rationale for the treatment of chronic urticaria with second-generation non-sedating antihistamines at higherthan-standard doses. J Eur Acad Dermatol Venereol. 2012;26:9-18.

17. Kaplan AP. What the first 10,000 patients with chronic urticaria have taught me: a personal journey. J Allergy Clin Immunol. 2009;123:713-7.

18. Grattan CE, Humphreys F. Guidelines for evaluation and management of urticaria in adults and children. Br J Dermatol. 2007;157:1116-23.

19. Church DS, Church MK. Pharmacology of antihistamines. World Allergy Organ J. 2011;4:S22-7.

20. Costa C, Gonçalo M, On behalf of GPEU - Grupo Português de Estudos de Urticária. Diagnostic and Therapeutic Approach of Chronic Spontaneous Urticaria: Recommendations in Portugal. Acta Med Port. 2016;29:763-81.

21. Stull D, McBride D, Balp MM. Patient preferences for health: the value patients place on differential severity of chronic spontaneous (idiopathic) urticaria (CSU/CIU). Copenhagen: EAACl; 2014.

22. Stull D, McBride D, Georgiou P, Zuberbier T, Grattan C, Balp MM. Measuring patient severity in chronic spontaneous/idiopathic urticaria (CSU/CIU) as categorical health states: efficient and informative? Copenhagen: EAACl; 2014.

23. Finlay AY, Khan GK. Dermatology Life Quality Index (DLQI)-a simple practical measure for routine clinical use. Clin Exp Dermatol. 1994;19:210-6.

24. Mlynek A, Zalewska-Janowska A, Martus $P$, Staubach $P$, Zuberbier T, Maurer M. How to assess disease activity in patients with chronic urticaria? Allergy. 2008;63:777-80.

25. Staubach $P$, Metz $M$, Chapman-Rothe N, Sieder C, Bräutigam M, Canvin $\mathrm{J}$, et al. Effect of omalizumab on angioedema in $\mathrm{H} 1$-antihistamineresistant chronic spontaneous urticaria patients: results from X-ACT, a randomized controlled trial. Allergy. 2016;71:1135-44.

26. Ferrer M. Epidemiology, healthcare, resources, use and clinical features of different types of urticaria. Alergologica 2005. J Investig Allergol Clin Immunol. 2009;19:S21-6.

27. Broder MS, Raimundo K, Antonova E, Chang E. Resource use and costs in an insured population of patients with chronic idiopathic/spontaneous urticaria. Am J Clin Dermatol. 2015;16:313-21.

28. Delong LK, Culler SD, Saini SS, Beck LA, Chen SC. Annual direct and indirect health care costs of chronic idiopathic urticaria: a cost analysis of 50 nonimmunosuppressed patients. Arch Dermatol. 2008;144:35-9.

29. Conlon NP, Abramovitch A, Murray G, O'Hanrahan A, Wallace $\mathrm{D}$, Holohan $\mathrm{K}$, et al. Allergy in Irish adults: a survey of referrals and outcomes at a major centre. Ir J Med Sci. 2015;184:349-52.

30. Maurer M, Ortonne JP, Zuberbier T. Chronic urticaria: a patient survey on quality-of-life, treatment usage and doctor-patient relation. Allergy. 2009;64:581-8.

31. Savic S, Marsland A, McKay D, Ardern-Jones MR, Leslie T, Somenzi O, et al. Retrospective case note review of chronic spontaneous urticaria outcomes and adverse effects in patients treated with omalizumab or ciclosporin in UK secondary care. Allergy Asthma Clin Immunol. 2015;11:21.

32. Silvares MR, Fortes MR, Miot HA. Quality of life in chronic urticaria: a survey at a public university outpatient clinic, Botucatu (Brazil). Rev Assoc Med Bras. 2011;57:577-82.

33. Engin B, Ozdemir M. Prospective randomized non-blinded clinical trial on the use of dapsone plus antihistamine vs. antihistamine in patients with chronic idiopathic urticaria. J Eur Acad Dermatol Venereol. 2008:22:481-6

34. Barbosa F, Freitas J, Barbosa A. Chronic idiopathic urticaria and anxiety symptoms. J Health Psychol. 2011;16:1038-47.

35. Zuberbier T, Balke M, Worm M, Edenharter G, Maurer M. Epidemiology of urticaria: a representative cross-sectional population survey. Clin Exp Dermatol. 2010;35:869-73.

36. Buyukozturk S, Gelincik A, Demirturk M, Kocaturk E, Colakoglu B, Dal M. Omalizumab markedly improves urticaria activity scores and quality of life scores in chronic spontaneous urticaria patients: a real life survey.
J Dermatol. 2012;39:439-42.

37. Ghazanfar MN, Sand C, Thomsen SF. Effectiveness and safety of omalizumab in chronic spontaneous or inducible urticaria: evaluation of 154 patients. Br J Dermatol. 2016;175:404-6.

38. Najib U, Bajwa ZH, Ostro MG, Sheikh J. A retrospective review of clinical presentation, thyroid autoimmunity, laboratory characteristics, and therapies used in patients with chronic idiopathic urticaria. Ann Allergy Asthma Immunol. 2009;103:496-501.

39. Sussman G, Hebert J, Barron C, Bian J, Caron-Guay RM, Laflamme S, et al. Real-life experiences with omalizumab for the treatment of chronic urticaria. Ann Allergy Asthma Immunol. 2014;112:170-4.

40. Tarbox JA, Gutta RC, Radojicic C, Lang DM. Utility of routine laboratory testing in management of chronic urticaria/angioedema. Ann Allergy Asthma Immunol. 2011;107:239-43.

41. Viswanathan RK, Biagtan MJ, Mathur SK. The role of autoimmune testing in chronic idiopathic urticaria. Ann Allergy Asthma Immunol. 2012;108:337-41.

42. Weller K, Ziege C, Staubach P, Brockow K, Siebenhaar F, Krause K, et al. H1-antihistamine up-dosing in chronic spontaneous urticaria: patients' perspective of effectiveness and side effects-a retrospective survey study. PLoS One. 2011;6:e23931.

43. Maurer M, Rosen K, Hsieh HJ, Saini S, Grattan C, Gimenéz-Arnau A, et al. Omalizumab for the treatment of chronic idiopathic or spontaneous urticaria. N Engl J Med. 2013;368:924-35.

44. Kaplan A, Ledford D, Ashby M, Canvin J, Zazzali JL, Conner E, et al. Omalizumab in patients with symptomatic chronic idiopathic/ spontaneous urticaria despite standard combination therapy. J Allergy Clin Immunol. 2013;132:101-9.

45. Saini SS, Bindslev-Jensen C, Maurer M, Grob JJ, Bülbül Baskan E, Bradley MS, et al. Efficacy and safety of omalizumab in patients with chronic idiopathic/spontaneous urticaria who remain symptomatic on H1 antihistamines: a randomized, placebo-controlled study. J Invest Dermatol. 2015;135:67-75.

46. Zazzali JL, Broder MS, Chang E, Chiu MW, Hogan DJ. Cost, utilization, and patterns of medication use associated with chronic idiopathic urticaria. Ann Allergy Asthma Immunol. 2012;108:98-102.

47. Maurer M, Staubach P, Raap U, Richter-Huhn G, Bauer A, Ruëff F, et al. H1-antihistamine-refractory chronic spontaneous urticaria: it's worse than we thought - first results of the multicenter real-life AWARE study. Clin Exp Allergy. 2017;47:684-92.

48. Thomsen SF, Pritzier EC, Anderson CD, Vaugelade-Baust N, Dodge $\mathrm{R}$, Dahlborn AK, et al. Chronic urticaria in the real-life clinical practice setting in Sweden, Norway and Denmark: baseline results from the noninterventional multicentre AWARE study. J Eur Acad Dermatol Venereol. 2017;31:1048-55

49. Furue M, Yamazaki S, Jimbow K, Tsuchida T, Amagai M, Tanaka T, et al. Prevalence of dermatological disorders in Japan: a nationwide, crosssectional, seasonal, multicenter, hospital-based study. J Dermatol. 2011;38:310-20.

50. Kang MJ, Kim HS, Kim HO, Park YM. The impact of chronic idiopathic urticaria on quality of life in korean patients. Ann Dermatol. 2009;21:2269.

51. Nam YH, Kim JH, Jin HJ, Hwang EK, Shin YS, Ye YM, et al. Effects of omalizumab treatment in patients with refractory chronic urticaria. Allergy Asthma Immunol Res. 2012;4:357-61.

52. Kaplan AP. Clinical practice. Chronic urticaria and angioedema. N Eng J Med. 2002;346:175-9.

53. Weller K, Schoepke N, Krause K, Ardelean E, Brautigam M, Maurer M Selected urticaria patients benefit from a referral to tertiary care centres-results of an expert survey. J Eur Acad Dermatol Venereol. 2013;27:e816.

54. Metz M, Ohanyan T, Church MK, Maurer M. Omalizumab is an effective and rapidly acting therapy in difficult-to-treat chronic urticaria: a retrospective clinical analysis. J Dermatol Sci. 2014;73:57-62.

55. Vietri J, Turner SJ, Tian H, Isherwood G, Balp MM, Gabriel S. Effect of chronic urticaria on US patients: analysis of the National Health and Wellness Survey. Ann Allergy Asthma Immunol. 2015;115:306-11.

56. Tian H, Chambenoit O, Chiva-Razavi S, Lynde C, Sussman G, Chapman-Rothe $\mathrm{N}$, et al. Healthcare resource utilisation among chronic spontaneous/idiopathic urticaria patients- findings from the first international burden of illness study (Assure-Csu). Value Health. 2015;18:A424.

57. Maurer M, Ortonne JP, Zuberbier T. Chronic urticaria: an internet survey of health behaviours, symptom patterns and treatment needs in European adult patients. Br J Dermatol. 2009;160:633-41. 